NASA/TM-2005-213061

\title{
Effect of Silicon Nitride Balls and Rollers on Rolling Bearing Life
}

Erwin V. Zaretsky

Glenn Research Center, Cleveland, Ohio

Brian L. Vlcek

Georgia Southern University, Statesboro, Georgia

Robert C. Hendricks

Glenn Research Center, Cleveland, Ohio 
Since its founding, NASA has been dedicated to the advancement of aeronautics and space science. The NASA Scientific and Technical Information (STI) Program Office plays a key part in helping NASA maintain this important role.

The NASA STI Program Office is operated by Langley Research Center, the Lead Center for NASA's scientific and technical information. The NASA STI Program Office provides access to the NASA STI Database, the largest collection of aeronautical and space science STI in the world. The Program Office is also NASA's institutional mechanism for disseminating the results of its research and development activities. These results are published by NASA in the NASA STI Report Series, which includes the following report types:

- $\quad$ TECHNICAL PUBLICATION. Reports of completed research or a major significant phase of research that present the results of NASA programs and include extensive data or theoretical analysis. Includes compilations of significant scientific and technical data and information deemed to be of continuing reference value. NASA's counterpart of peerreviewed formal professional papers but has less stringent limitations on manuscript length and extent of graphic presentations.

- TECHNICAL MEMORANDUM. Scientific and technical findings that are preliminary or of specialized interest, e.g., quick release reports, working papers, and bibliographies that contain minimal annotation. Does not contain extensive analysis.

- CONTRACTOR REPORT. Scientific and technical findings by NASA-sponsored contractors and grantees.
- CONFERENCE PUBLICATION. Collected papers from scientific and technical conferences, symposia, seminars, or other meetings sponsored or cosponsored by NASA.

- SPECIAL PUBLICATION. Scientific, technical, or historical information from NASA programs, projects, and missions, often concerned with subjects having substantial public interest.

- TECHNICAL TRANSLATION. Englishlanguage translations of foreign scientific and technical material pertinent to NASA's mission.

Specialized services that complement the STI Program Office's diverse offerings include creating custom thesauri, building customized databases, organizing and publishing research results ... even providing videos.

For more information about the NASA STI Program Office, see the following:

- Access the NASA STI Program Home Page at http://www.sti.nasa.gov

- E-mail your question via the Internet to help@sti.nasa.gov

- Fax your question to the NASA Access Help Desk at 301-621-0134

- Telephone the NASA Access Help Desk at 301-621-0390

- Write to:

NASA Access Help Desk

NASA Center for AeroSpace Information 7121 Standard Drive

Hanover, MD 21076 
NASA/TM-2005-213061

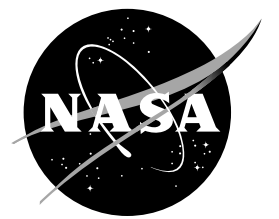

\section{Effect of Silicon Nitride Balls and Rollers on Rolling Bearing Life}

Erwin V. Zaretsky

Glenn Research Center, Cleveland, Ohio

Brian L. Vlcek

Georgia Southern University, Statesboro, Georgia

Robert C. Hendricks

Glenn Research Center, Cleveland, Ohio

Prepared for the

2004 International Joint Tribology Conference cosponsored by the American Society of Mechanical Engineers and the Society of Tribologists and Lubrication Engineers

Long Beach, California, October 24-27, 2004

National Aeronautics and

Space Administration

Glenn Research Center 
Available from

NASA Center for Aerospace Information 7121 Standard Drive

Hanover, MD 21076
National Technical Information Service 5285 Port Royal Road Springfield, VA 22100

Available electronically at http://gltrs.grc.nasa.gov 


\title{
Effect of Silicon Nitride Balls and Rollers on Rolling Bearing Life
}

\author{
Erwin V. Zaretsky \\ National Aeronautics and Space Administration \\ Glenn Research Center \\ Cleveland, Ohio 44135 \\ Brian L. Vlcek \\ Georgia Southern University \\ Statesboro, Georgia 30460 \\ Robert C. Hendricks \\ National Aeronautics and Space Administration \\ Glenn Research Center \\ Cleveland, Ohio 44135
}

\begin{abstract}
Summary
Three decades have passed since the introduction of silicon nitride rollers and balls into conventional rolling-element bearings. For a given applied load, the contact (Hertz) stress in a hybrid bearing will be higher than an all-steel rolling-element bearing. The silicon nitride rolling-element life as well as the lives of the steel races were used to determine the resultant bearing life of both hybrid and all-steel bearings. Life factors were determined and reported for hybrid bearings. Under nominal operating speeds, the resultant calculated lives of the deep-groove, angular-contact, and cylindrical roller hybrid bearings with races made of post-1960 bearing steel increased by factors of 3.7, 3.2, and 5.5, respectively, from those calculated using the Lundberg-Palmgren equations. An all-steel bearing under the same load will have a longer life than the equivalent hybrid bearing under the same conditions. Under these conditions, hybrid bearings are predicted to have a lower fatigue life than all-steel bearings by 58 percent for deep-groove bearings, 41 percent for angular-contact bearings, and 28 percent for cylindrical roller bearings.
\end{abstract}

\section{Introduction}

In 1970, Dee (ref. 1) first proposed hot-pressed silicon nitride for rolling-element bearings as well as for journal bearings. A review of the development of silicon nitride for rolling-element bearing application can be found in references 2 and 3. Rolling-element fatigue testing of hot-pressed silicon nitride has resulted in several seemingly contradictory results.

Poor life results were obtained in the limited tests reported by Scott et al. (refs. 4 and 5) in 1971 and 1973. The results reported by Baumgartner et al. (refs. 6 to 8 ) in 1973 showed the rolling-element fatigue life of hot-pressed silicon nitride to exceed that of a typical rolling-element bearing steel. Extrapolation of the experimental results of Parker and Zaretsky (ref. 9) to contact loads that result in stress levels typical of those in rolling-element bearing applications indicate that hot-pressed silicon nitride running against steel may be expected to yield fatigue lives comparable to or greater than those of bearing quality steel running against steel (ref. 10).

In an attempt to resolve these differences, concurrent with the work of Dee (ref. 1), Scott et al. (ref. 4) and (ref. 5), Baumgartner et al. (refs. 6 to 8), and Parker and Zaretsky (ref. 9), hybrid bearings comprising silicon nitride rolling-elements and steel races were manufactured and tested (refs. 6 to 7 and 11 to 16) as well as all ceramic bearings comprising silicon nitride rolling elements and rings (refs. 6, 17, and 18). From references 8, 9, and 18, the Hertz stress-life exponent $\boldsymbol{n}$ for silicon nitride ranged from 16 to 
16.2 with an average value of 16.1 (ref. 10). These values are much higher than those for steel, which range from 9 to 12 .

Morrison et al. (ref. 20) tested four groups of hybrid 45-mm-bore angular-contact ball bearings having vacuum induction melted-vacuum arc melted (VIM-VAR) AISI M-50 steel races and silicon nitride balls. The bearings were tested at four thrust loads. The loads produced inner-race maximum Hertz stresses of 1.95, 2.0, 2.17, and $2.44 \mathrm{GPa}(283,290,315$, and $354 \mathrm{ksi})$, respectively. All of the failures for each thrust load were spalling of a silicon nitride ball. There were no failures of the steel raceways. The life and dynamic capacity of the hybrid bearing were less than the theoretical life and capacity of all-steel AISI M-50 steel ball bearings.

Morrison et al. (ref. 20) reported that the load-life exponent $\boldsymbol{p}$ for the hybrid bearings was 4.29 with 95 percent confidence limits of 3.16 and 5.42. Based upon a load-life exponent of 4.29, the Hertz stresslife exponent $\boldsymbol{n}$ for these ball bearings is approximately 13, which is solely a function of the failure of the silicon nitride balls. From the experimental data, the actual Hertz stress-life exponent $\boldsymbol{n}$ of this silicon nitride hybrid bearing was approximately 14 . These values are not significantly less than those obtained in references 8,9 , and 19 .

In 1986, Komeya and Kotani (ref. 21) concluded that "silicon nitride (hybrid bearings) retains a rolling life equivalent to or better than that of conventional bearing steel." Subsequent work reported by Tanimoto and Ikeda (ref. 22) and Tanimoto, Kajihara and Yanai (ref. 23) concluded that the rollingelement fatigue life of silicon nitride was over two times that of bearing steel and that the life of hybrid bearings was five times that predicted. These results suggest significantly higher lives are obtained than those predicted for these hybrid bearings.

These apparent differences in the literature are not totally contradictory. For a given applied load the contact (Hertz) stress in a hybrid bearing containing silicon nitride rolling elements and steel races will be higher than in an all-steel rolling-element bearing where all the components are manufactured from hardened bearing steel. This is because the modulus of elasticity of the silicon nitride is approximately 1.5 times that of a typical bearing steel.

From the work reported by Zaretsky (refs. 10, 24, and 25) and the analysis in appendix A that examines the effect of the modulus of elasticity and Poisson's ratio on contact stress (these are based upon the bearing life analysis of Lundberg and Palmgren (ref. 26), it was concluded that because of the higher modulus of elasticity, the life of a hybrid bearing will be less than that of an all-steel bearing of the same design and under the same load. The problem is that the Lundberg-Palmgren (ref. 26) life equation does not consider the life of the rolling elements independent of the race lives, nor does it consider differences in the modulus of elasticity or the Hertz stress-life exponent.

In view of the aforementioned, it is the objectives of the work reported herein to (a) account for the differences in material properties, including the Hertz stress-life exponents, between the rolling elements and races, (b) account for the lives of the rolling-element as well as the race to determine the resultant bearing life, and (c) theoretically compare the predicted lives of hybrid silicon nitride bearings both with that predicted for all-steel bearings and the actual lives reported in the literature.

\section{Nomenclature}

$\begin{array}{ll}\boldsymbol{a} & \text { semi-major axis of contact ellipse, m (in.) } \\ \boldsymbol{b} & \text { one-half line contact width, m (in.) } \\ \boldsymbol{C}_{\boldsymbol{D}} & \text { dynamic load capacity, N (lbf) } \\ \boldsymbol{c} & \text { stress-life exponent } \\ \boldsymbol{D} \boldsymbol{N} & \text { speed parameter, bearing bore in mm times bearing speed in rpm } \\ \boldsymbol{e} & \text { Weibull slope } \\ \boldsymbol{h} & \text { exponent } \\ \boldsymbol{K} & \text { geometry-load constant }\end{array}$




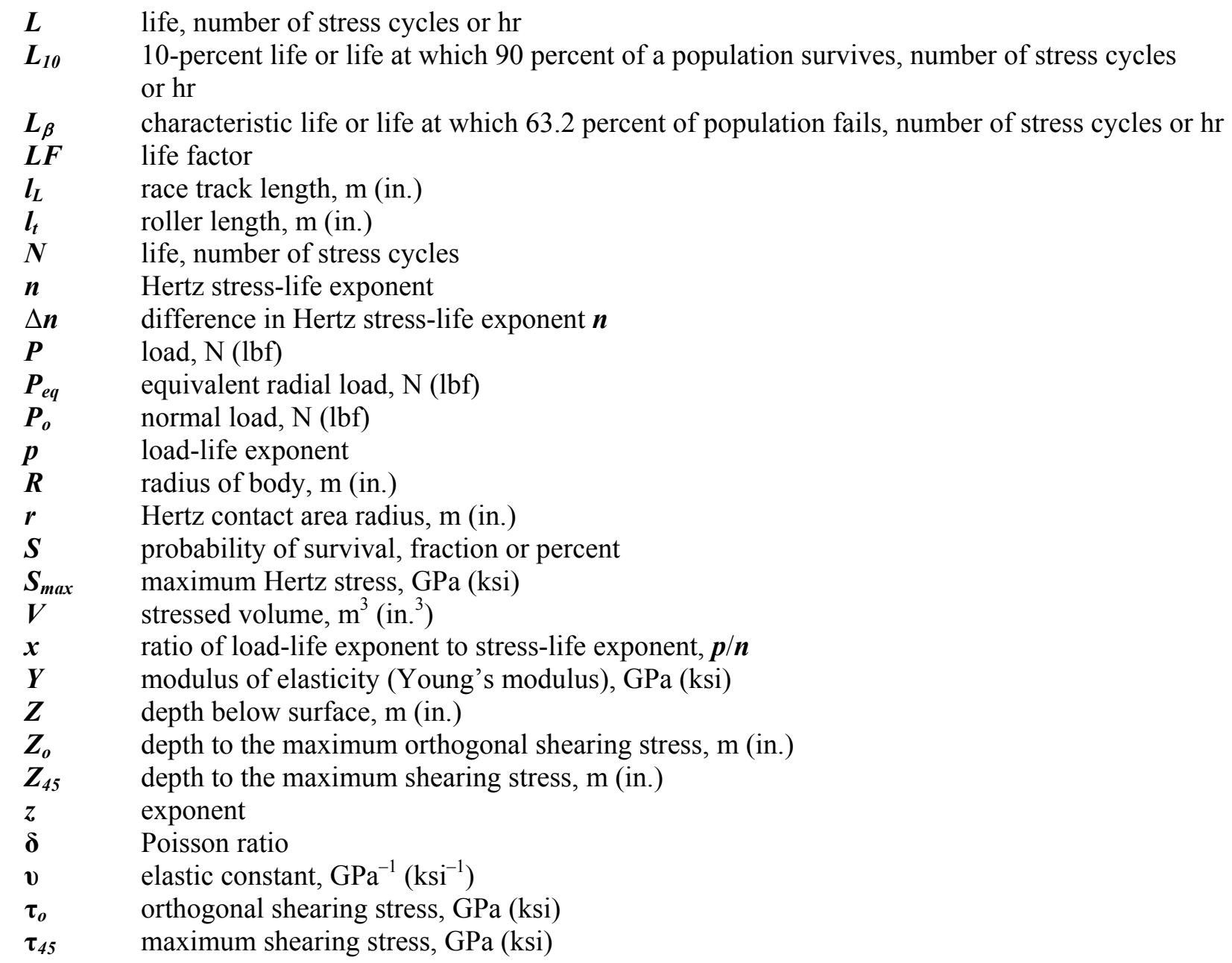

\begin{tabular}{ll}
\multicolumn{2}{l}{ Subscripts } \\
$\boldsymbol{a}, \boldsymbol{b}$ & body a or b \\
$\boldsymbol{c}$ & ceramic \\
$\boldsymbol{H}$ & hybrid bearing \\
$\boldsymbol{i} \boldsymbol{r}$ & inner race \\
$\boldsymbol{L P}$ & Lundberg-Palmgren \\
$\boldsymbol{o r}$ & outer race \\
$\boldsymbol{r} \boldsymbol{e}$ & rolling elements \\
$\boldsymbol{S}$ & all-steel bearing \\
$\boldsymbol{S}$ & steel \\
$\boldsymbol{S N}$ & silicon nitride \\
$\mathbf{5 2 1 0 0}$ & CVM AISI 52100 steel
\end{tabular}




\section{Bearing Life Analysis}

\section{Lundberg-Palmgren Equation}

In probabilistic life models, the bearing physical characteristics, applied load, operating profile, and environment determine the probability of failure, assuming that the life is represented by a known probability function. Weibull (refs. 27 to 29) was the first to suggest a reasonable way to estimate material fracture strength with such a probability function. Based upon the work of Weibull (refs. 27 to 29), G. Lundberg and A. Palmgren (ref. 26) in 1947 showed that the probability of survival $\boldsymbol{S}$ could be expressed as a power function of the orthogonal shearing stress $\tau_{\boldsymbol{o}}$, life $N$, depth to the maximum orthogonal shear stress $\boldsymbol{Z}_{\boldsymbol{o}}$, and stressed volume $\boldsymbol{V}$. That is,

$$
\ln \frac{1}{S} \sim \tau_{o}^{c} \frac{N^{e}}{Z_{o}^{h}} V
$$

From equation (1) and for some constant $\boldsymbol{S}$,

$$
L=N \sim\left(\frac{1}{\tau_{o}}\right)^{c / e}\left(\frac{1}{V}\right)^{1 / e}\left[Z_{o}\right]^{h / e}
$$

where for ball bearings,

$$
V=a l_{L} Z_{o}
$$

and for roller bearings,

$$
V=l_{t} l_{L} Z_{o}
$$

The resultant variables in equations (3) and (4) are defined in figure 1(a) and (b).

Lundberg and Palmgren (ref. 26) incorporated into their analysis a method and distribution function for statistically describing the fatigue life of materials developed by Weibull (ref. 27) referred to as the two-parameter Weibull distribution function:

$$
\ln \ln \frac{1}{\boldsymbol{S}}=\boldsymbol{e} \ln \left(\frac{\boldsymbol{L}}{\boldsymbol{L}_{\beta}}\right), \text { where } 0<\boldsymbol{L}<\infty ; 0<\boldsymbol{S}<1
$$

From equation (5), Lundberg and Palmgren (ref. 26) first derived the relationship between individual component life and system life. A bearing is a system of multiple components, each with a different life. As a result, the life of the system is different from the life of an individual component in the system. The system life can be expressed to a first order as

$$
\frac{1}{L_{10}{ }^{e}}=\frac{1}{L_{10 i r}{ }^{e}}+\frac{1}{L_{10 o r}{ }^{e}}
$$



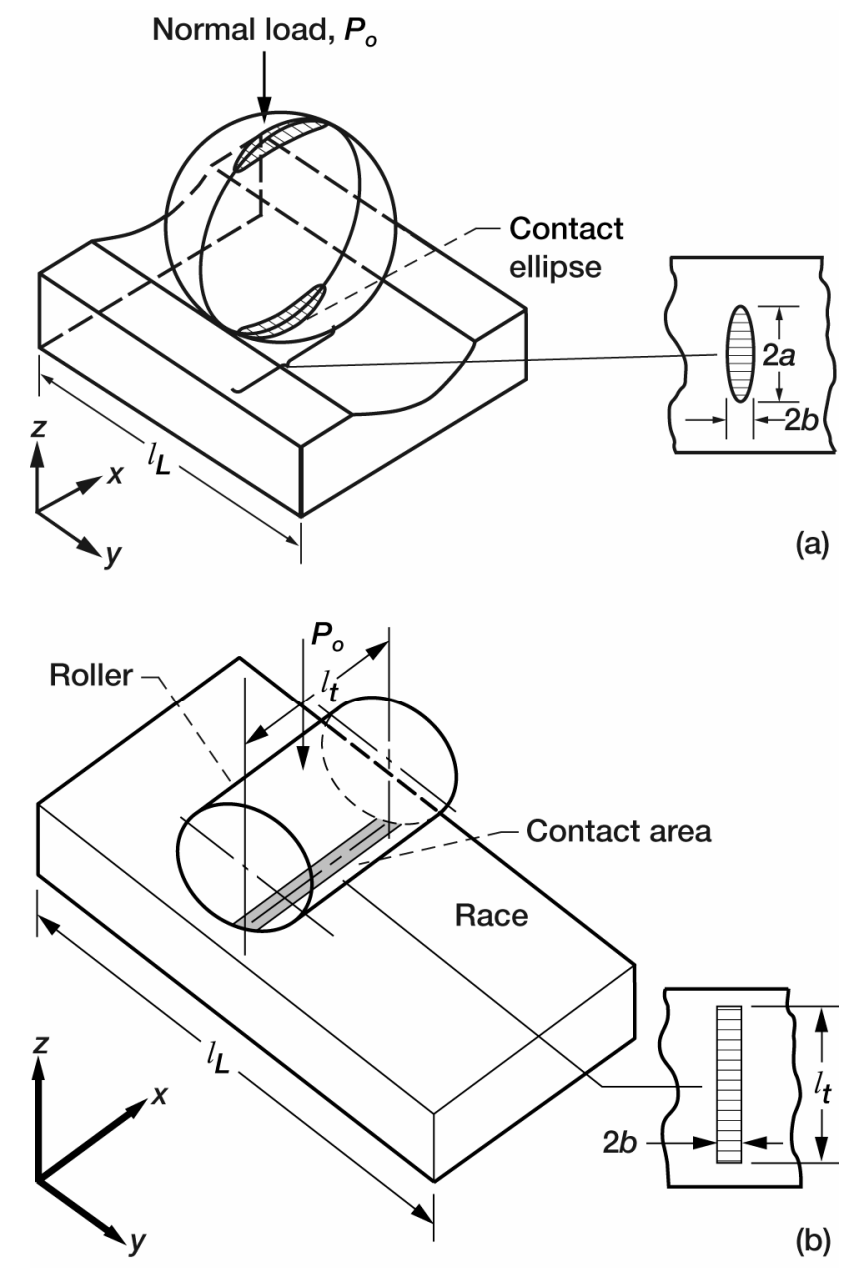

Figure 1.-Schematic of contact profile of rolling element on raceway. (a) Ball on raceway. (b) Roller on raceway.

where the life of the rolling elements, by inference, is incorporated into the life of each raceway tacitly assuming that all components have the same Weibull slope $\boldsymbol{e}$. In properly designed and operated rollingelement bearings, fatigue of the cage or separator should not occur and, therefore, is not considered in determining bearing life and reliability.

From equations (1) and (6), Lundberg and Palmgren (ref. 26) derived the following relation:

$$
\boldsymbol{L}_{10}=\left[\frac{\boldsymbol{C}_{\boldsymbol{D}}}{\boldsymbol{P}_{\boldsymbol{e q}}}\right]^{\boldsymbol{p}}
$$

For equation (7), the load-life exponent $\boldsymbol{p}$ equals 3 for ball bearings and 4 for roller bearings. However, for roller bearings, Lundberg and Palmgren (ref. 30) conservatively choose to use the load-life exponent $\boldsymbol{p}$ equals $10 / 3$. 


\section{Zaretsky Equation}

The work of E.V. Zaretsky (ref. 31) builds upon the work of Weibull (ref. 27) and Lundberg and Palmgren (ref. 26). Zaretsky eliminates the dependency of the stress-life relation on the Weibull slope $\boldsymbol{e}$. The dependence of the depth to the critical shearing stress $\boldsymbol{Z}_{45}$ is reformulated. He also uses the maximum shear stress $\tau_{45}$ instead of the orthogonal shear stress $\boldsymbol{\tau}_{\boldsymbol{o}}$ as the critical shearing stress. equation (1) becomes

$$
\ln \frac{1}{S} \sim \tau_{45}^{c e} N^{e} V
$$

For ball bearings, the stressed volume is

$$
V=a l_{L} Z_{45}
$$

and for roller bearings,

$$
V=\boldsymbol{l}_{\boldsymbol{t}} \boldsymbol{l}_{\boldsymbol{L}} \boldsymbol{Z}_{45}
$$

From equation (8), the life of each bearing component can be derived where

$$
\boldsymbol{L}=\boldsymbol{N} \sim\left(\frac{1}{\tau_{45}}\right)^{c}\left(\frac{1}{V}\right)^{1 / e}
$$

\section{Zaretsky's Rule}

To apply Zaretsky's rule (ref. 24), equation (6) should be written as follows:

$$
\left(\frac{1}{L_{10}}\right)^{e}=\left(\frac{1}{L_{i r}}\right)^{e}+\left(\frac{1}{L_{r e}}\right)^{e}+\left(\frac{1}{L_{o r}}\right)^{e}
$$

where the Weibull slope $\boldsymbol{e}$ is the same for each of the components as well as for the bearing as a system.

For radially loaded ball and roller bearings, the life of the rolling element set is equal to or greater than the life of the outer race. Let the life of the rolling element set (as a system) be equal to that of the outer race.

From equation (11)

$$
\left(\frac{1}{L_{10}}\right)^{e}=\left(\frac{1}{L_{i r}}\right)^{e}+2\left(\frac{1}{L_{o r}}\right)^{e}
$$

where $\boldsymbol{L}_{r e}=\boldsymbol{L}_{\text {or }}$

For thrust loaded ball and roller bearings, the life of the rolling element set is equal to or greater than the life of the inner race but less than that of the outer race. Let the life of the rolling element set (as a system) be equal to that of the inner race.

From equation (11) 


$$
\left(\frac{1}{L_{10}}\right)^{e}=2\left(\frac{1}{L_{i r}}\right)^{e}+\left(\frac{1}{L_{o r}}\right)^{e}
$$

where $\boldsymbol{L}_{r e}=\boldsymbol{L}_{\text {ir }}$

Examples for using equations (11) to (13) are given in Zaretsky (ref. 24). As previously stated, the resulting values for $\boldsymbol{L}_{\boldsymbol{i r}}$ and $\boldsymbol{L}_{\boldsymbol{o r}}$ from these equations are not the same as those from equation (6). From the Zaretsky analysis, equation (7) remains unchanged. However, the values of the load-life exponent $\boldsymbol{p}$ become 4 and 5 for ball and roller bearings, respectively.

\section{Effect of Elastic Constants}

From the Hertz equations for stresses in concentrated contacts (ref. 32),

$$
S_{\max } \sim \boldsymbol{P}^{x}
$$

where for ball bearings (point contact) with $\boldsymbol{x}=1 / 3$,

$$
S_{\max } \sim \boldsymbol{P}^{1 / 3}
$$

and for roller bearings (line contact) with $\boldsymbol{x}=1 / 2$,

$$
S_{\max } \sim \boldsymbol{P}^{1 / 2}
$$

From equations (7) and (14a),

$$
L \sim \frac{1}{P^{p}} \sim \frac{1}{S^{n}{ }_{\max }}
$$

where

$$
n=\frac{p}{x}
$$

and the ratio of the load-life exponent $\boldsymbol{p}$ to the Hertz stress-life exponent $\boldsymbol{n}$ is

$$
x=\frac{p}{n}
$$

From equations (14b) and (15c), for point contact (ball bearings) $\boldsymbol{n}$ equals 9 when $\boldsymbol{p}$ equals 3 , or 12 when $\boldsymbol{p}$ equals 4 , and from equations (14c) and (15c), for line contact (roller bearings) when $\boldsymbol{p}$ equals $10 / 3,4$, or 5 , then $\boldsymbol{n}$ equals $6.66,8$, and 10 , respectively.

From appendix A, equation (A15), the life of a hybrid bearing having a steel raceway with a ceramic rolling element and the same normal load $\boldsymbol{P}_{\boldsymbol{o}}$ as a steel rolling element in contact with a steel raceway, the life of the hybrid bearing raceway is 


$$
L_{H}=L_{S}\left(\frac{S_{\max S}}{S_{\max H}}\right)^{n}
$$

Let:

$$
L F=\frac{L_{H}}{L_{S}}
$$

From appendix A, equations (A14) and (A19),

$$
\boldsymbol{L F}_{\boldsymbol{H}}=\left[1 / 2+\frac{\boldsymbol{Y}_{\boldsymbol{s}}\left(1-\delta_{c}^{2}\right)}{2 \boldsymbol{Y}_{\boldsymbol{c}}\left(1-\delta_{s}^{2}\right)}\right]^{z \boldsymbol{n}}
$$

For point contact (ball bearings) $\boldsymbol{z}$ equals $2 / 3$ and for line contact (roller bearings) $\boldsymbol{z}$ equals $1 / 2$.

The elastic modulus $\boldsymbol{Y}$ and Poisson's ratio $\delta$ for both bearing steel $(\boldsymbol{s})$ and silicon nitride ceramic $(\boldsymbol{c})$ are given in table 1 . These values are from reference 22 . Table 2 summarizes the resultant life factors $\boldsymbol{L F}_{\boldsymbol{H}}$ for point and line contact for a combination of values for $\boldsymbol{n}, \boldsymbol{p}$, and $\boldsymbol{z}$ for silicon nitride rolling elements on a steel raceway.

TABLE 1.-MATERIAL ELASTIC PROPERTIES FOR BEARING STEEL AND SILICON NITRIDE

\begin{tabular}{|c|c|c|}
\hline \multirow{2}{*}{ Elastic constant } & \multicolumn{2}{|c|}{ Material $^{\mathrm{a}}$} \\
\cline { 2 - 3 } & $\begin{array}{c}\text { Silicon } \\
\text { nitride }\end{array}$ & $\begin{array}{c}\text { Bearing } \\
\text { steel }\end{array}$ \\
\hline $\begin{array}{c}\text { Young's modulus of elasticity, } \\
\boldsymbol{Y}, \\
\mathrm{GPa} \text { (psi) }\end{array}$ & $\begin{array}{c}310 \\
\left(45 \times 10^{6}\right)\end{array}$ & $\begin{array}{c}210 \\
\left(30.5 \times 10^{6}\right)\end{array}$ \\
\hline $\begin{array}{c}\text { Poisson's ratio, } \\
\delta\end{array}$ & 0.29 & 0.30 \\
\hline
\end{tabular}

${ }^{\mathrm{a}}$ Data from ref. 22.

TABLE 2.-LIFE FACTORS, $\boldsymbol{L F}_{\boldsymbol{H}}$, FOR BEARING STEEL

\begin{tabular}{|c|c|c|c|c|}
\hline \multicolumn{3}{|c|}{ Exponent } & \multirow{2}{*}{$\begin{array}{c}\text { Life factor, } \\
{ }^{\mathrm{b}} \boldsymbol{L} \boldsymbol{F}_{\boldsymbol{H}}\end{array}$} & \multirow{2}{*}{$\begin{array}{c}\text { Life reduction, } \\
\text { percent }\end{array}$} \\
\hline${ }^{\mathrm{a}} \boldsymbol{p}$ & ${ }^{\mathrm{a}} n$ & $\mathrm{~b}_{z}$ & & \\
\hline \multicolumn{5}{|c|}{ Point contact } \\
\hline 3 & 9 & $2 / 3$ & 0.35 & 65 \\
\hline 4 & 12 & $2 / 3$ & 0.25 & 75 \\
\hline \multicolumn{5}{|c|}{ Line contact } \\
\hline $10 / 3$ & $6 \frac{2}{3}$ & $1 / 2$ & 0.56 & 44 \\
\hline 4 & 8 & $1 / 2$ & 0.50 & 50 \\
\hline 5 & 10 & $1 / 2$ & 0.42 & 58 \\
\hline
\end{tabular}
RACES IN POINT AND LINE CONTACT WITH SILICON NITRIDE ROLLING ELEMENTS

${ }^{a}$ From eqs. (15a) and (15b).

${ }^{\mathrm{b}}$ From eq. (17). 


\section{Rolling-Element Life}

There are conflicting data comparing the rolling-element fatigue life of typical bearing steels and that of silicon nitride. These data were obtained in bench type rolling-element fatigue testers under point contact and at very high stress levels. Parker and Zaretsky (refs. 9 and 10) show a comparison of life data for hot-pressed silicon nitride and consumable-electrode vacuum melted (CVM) AISI 52100 and CVM AISI M-50 steels at a maximum Hertz stress of $5.52 \mathrm{GPa}(800 \mathrm{ksi})$. The $\boldsymbol{L}_{10}$ life of the silicon nitride balls was approximately $1 / 8$ that of the AISI 52100 balls and $1 / 5$ that of the AISI M-50 balls. Baumgartner et al. (refs. 6 to 8) reported opposite results at a maximum Hertz stress of $4.83 \mathrm{GPa}$ (700 ksi) where the life of the CVM M-50 steel was $1 / 8$ that of the silicon nitride rolling elements.

Assuming the equal validity of both tests, based upon an experimentally determined Hertz stress-life exponent $\boldsymbol{n}$ of 16 for silicon nitride in point contact, it can be reasonably concluded that there is a crossover between the life obtained with the silicon nitride material and the bearing steels; at the lower stress levels where rolling bearings are usually run, the silicon nitride material will produce longer lives than the bearing steels. Normalizing the life of silicon nitride in point contact to the Lundberg-Palmgren calculated life $\boldsymbol{L}_{\boldsymbol{L} \boldsymbol{P}}$ from reference 23, the life factor $\boldsymbol{L F}$ for CVM AISI 52100 bearing steel is 6 where

$$
\boldsymbol{L}_{52100}=6 \boldsymbol{L}_{\boldsymbol{L P}}
$$

At a maximum Hertz stress of $5.52 \mathrm{GPa}(800 \mathrm{ksi})$,

$$
\boldsymbol{L}_{\boldsymbol{S N}}=\frac{1}{8} \boldsymbol{L}_{52100}
$$

Therefore,

$$
\boldsymbol{L}_{S N}=\frac{6}{8} \boldsymbol{L}_{L P}
$$

Based upon a Hertz stress-life exponent $\boldsymbol{n}$ for silicon nitride of 16 and from equations (15a) and (18c), the life at any stress for silicon nitride normalized to a maximum Hertz stress of $5.52 \mathrm{GPa}$ (800 ksi) is

$$
\boldsymbol{L}_{\boldsymbol{S N}}=0.75 \boldsymbol{L}_{\boldsymbol{L P}}\left(\frac{5.52 \mathrm{GPa}}{\boldsymbol{S}_{\max }}\right)^{16}=0.75 \boldsymbol{L}_{\boldsymbol{L P}}\left(\frac{800 \mathrm{ksi}}{\boldsymbol{S}_{\max }}\right)^{16}
$$

For steel with $\boldsymbol{n}$ of 9 ,

$$
\boldsymbol{L}_{\boldsymbol{S N}}=\boldsymbol{L}_{\boldsymbol{L P}}\left(\frac{5.52 \mathrm{GPa}}{\boldsymbol{S}_{\max }}\right)^{9}=\boldsymbol{L}_{\boldsymbol{L P}}\left(\frac{800 \mathrm{ksi}}{\boldsymbol{S}_{\max }}\right)^{9}
$$


To determine a life factor for silicon nitride $\boldsymbol{L} \boldsymbol{F}_{S N}$ relative to the Lundberg-Palmgren calculated life for generic bearing steel in point contact, equation (19a) is divided by equation (19b). For a generic bearing steel in point contact, $9 \leq \boldsymbol{n} \leq 12$. Where for steel let $\boldsymbol{n}=9$,

$$
\begin{aligned}
\boldsymbol{L F}_{\boldsymbol{S N}}=\frac{\boldsymbol{L}_{\boldsymbol{S N}}}{\boldsymbol{L}_{\boldsymbol{S}}}=0.75\left(\frac{5.52 \mathrm{GPa}}{\boldsymbol{S}_{\max }}\right)^{\Delta \boldsymbol{n}} & =0.75\left(\frac{5.52 \mathrm{GPa}}{\boldsymbol{S}_{\max }}\right)^{(16-9)} \\
& =0.75\left(\frac{5.52 \mathrm{GPa}}{\boldsymbol{S}_{\max }}\right)^{7}=0.75\left(\frac{800 \mathrm{ksi}}{\boldsymbol{S}_{\max }}\right)^{7}
\end{aligned}
$$

If the Hertz stress-life exponent $\boldsymbol{n}$ for generic bearing steel is taken as 12, then the exponent $\Delta \boldsymbol{n}$ in equation (20) is 4.

The relationship between Hertz stress and life also accounts for the change in stressed volume. For point contact,

$$
V \sim S_{\max }^{2}
$$

For line contact,

$$
V \sim S_{\max }
$$

From the analysis in appendix B, it was determined the Hertz stress-life exponent for silicon nitride in line contact is $\boldsymbol{n}=15.5$. For a generic bearing steel, in line contact, $6.666 \leq \boldsymbol{n} \leq 10$. Where for steel let $\boldsymbol{n}=8$,

$$
\begin{aligned}
\boldsymbol{L F}_{\boldsymbol{S N}}=\frac{\boldsymbol{L}_{\boldsymbol{S N}}}{\boldsymbol{L}_{\boldsymbol{S}}}=0.75\left(\frac{5.52 \mathrm{GPa}}{\boldsymbol{S}_{\max }}\right)^{\Delta \boldsymbol{n}} & =0.75\left(\frac{5.52 \mathrm{GPa}}{\boldsymbol{S}_{\max }}\right)^{(15.5-8)} \\
& =0.75\left(\frac{5.52 \mathrm{GPa}}{\boldsymbol{S}_{\max }}\right)^{7.5}=0.75\left(\frac{800 \mathrm{ksi}}{\boldsymbol{S}_{\max }}\right)^{7.5}
\end{aligned}
$$

If $\boldsymbol{n}$ equals 15.5 for silicon nitride and 10 for steel, then the exponent $\Delta \boldsymbol{n}$ for equation (22) is 5.5 .

Table 3, based on equations (20) and (22), summarizes life factor for silicon nitride $\boldsymbol{L F}_{\boldsymbol{S N}}$ relative to the Lundberg-Palmgren life equation for bearing steel. These factors are presented for different values of $\Delta \boldsymbol{n}$, the difference between the Hertz stress-life exponent of silicon nitride and bearing steel. 


\begin{tabular}{|c|c|c|}
\hline $\begin{array}{c}\text { Exponent, } \\
\Delta \boldsymbol{n}\end{array}$ & $\begin{array}{c}\text { Maximum } \\
\text { Hertz stress, } \\
\text { GPa (ksi) }\end{array}$ & $\begin{array}{l}\text { Life factor, } \\
\qquad \boldsymbol{L} \boldsymbol{F}_{S N}\end{array}$ \\
\hline \multicolumn{3}{|c|}{ Point contact, eq. (20) } \\
\hline \multirow[t]{4}{*}{7} & $2.93(425)$ & 63 \\
\hline & $2.41(350)$ & 245 \\
\hline & $1.90(275)$ & 1322 \\
\hline & $1.38(200)$ & 12288 \\
\hline \multirow[t]{4}{*}{4} & $2.93(425)$ & 9.4 \\
\hline & $2.41(350)$ & 20.5 \\
\hline & $1.90(275)$ & 54 \\
\hline & $1.38(200)$ & 192 \\
\hline \multicolumn{3}{|c|}{ Line contact, eq. (22) } \\
\hline \multirow[t]{4}{*}{8.8} & $2.93(425)$ & 196 \\
\hline & $2.41(350)$ & 1083 \\
\hline & $1.90(275)$ & 9039 \\
\hline & $1.38(200)$ & 149001 \\
\hline \multirow[t]{4}{*}{7.5} & $2.93(425)$ & 86 \\
\hline & $2.41(350)$ & 370 \\
\hline & $1.90(275)$ & 2256 \\
\hline & $1.38(200)$ & 24576 \\
\hline \multirow[t]{4}{*}{5.5} & $2.93(425)$ & 24.3 \\
\hline & $2.41(350)$ & 71 \\
\hline & $1.90(275)$ & 267 \\
\hline & $1.38(200)$ & 1536 \\
\hline
\end{tabular}

\section{Results and Discussion}

Three decades have passed since the introduction of silicon nitride rollers and balls into conventional rolling-element bearings. These bearings are referred to as "hybrid rolling-element bearings." For an applied bearing load, the resultant Hertz stress in a hybrid bearing is higher than that in an all-steel bearing. Thus, based upon the Lundberg-Palmgren life theory, where only the life of the races are considered, the predicted life of a hybrid bearing is less than that of an all-steel bearing under the same conditions. However, results in the literature suggest that significantly higher lives are obtained than those predicted for these hybrid bearings.

Three types of representative 50-mm-bore rolling-element bearings whose specifications are summarized in table 4 are used to illustrate the analysis for hybrid bearings previously discussed. These are a deep-groove ball bearing, an angular-contact ball bearing, and a cylindrical roller bearing. The bearings are assumed to operate at a speed of $10000 \mathrm{rpm}(500000 \mathrm{DN})$. For all the bearings the maximum Hertz stress at the inner race for an all-steel bearing is assumed to be $1.72 \mathrm{GPa}(250 \mathrm{ksi})$. Accordingly, the load for each type of bearing to achieve this stress as well as the dynamic load capacity $C_{D}$ will be different.

The resultant stresses on each of the respective raceways when the steel rolling elements are replaced with silicon nitride rolling elements is also shown in table 4 . The silicon nitride balls increase the maximum Hertz stress on each of the raceways by approximately 12.8 percent. For roller bearings, the maximum Hertz stress increases by approximately 9.6 percent. Based upon equation (17), life factors $\boldsymbol{L F}_{\boldsymbol{H}}$ for both ball and roller bearings are given in table 2 based upon various values the Hertz stress-life 
exponent $\boldsymbol{n}$. When these life factors are applied against the Lundberg-Palmgren equation (equation (7)), reductions in bearing life of 65 and 44 percent occur for ball and roller bearings, respectively. For the three example bearings these results are summarized in table 5, where the Weibull slopes $\boldsymbol{e}_{S}=1.11$ and $\boldsymbol{e}_{S N}=1.7$. The effect of material and processing factors for CVM AISI 52100 steel and VIM-VAR AISI M-50 steel are also shown in table 5 as applied to the basic Lundberg-Palmgren equation. This approach, first presented by Zaretsky (refs. 10, 24, and 25), will result in values of the predicted life for the hybrid rolling-element bearings with silicon nitride rolling elements that are lower than can be achieved in actual application.

TABLE 4.-BEARING SPECIFICATION AND OPERATING CONDITIONS USED FOR BEARING LIFE ANALYSIS

\begin{tabular}{|c|c|c|c|c|}
\hline \multicolumn{2}{|c|}{ Bearing type } & $\begin{array}{c}\text { Deep-groove } \\
\text { ball bearing }\end{array}$ & $\begin{array}{l}\text { Angular-contact } \\
\text { ball bearing }\end{array}$ & $\begin{array}{c}\text { Cylindrical } \\
\text { roller bearing }\end{array}$ \\
\hline \multicolumn{2}{|l|}{ Bore size, $\mathrm{mm}$} & 50 & 50 & 50 \\
\hline \multirow[t]{2}{*}{ Curvatures, percent } & Inner race & 52 & 52 & -------------------- \\
\hline & Outer race & 52 & 52 & --------------------- \\
\hline \multicolumn{2}{|c|}{ Ball or roller diameter, mm (in.) } & $8.73(11 / 32)$ & $8.73(11 / 32)$ & $9.92(25 / 64)$ \\
\hline \multicolumn{2}{|c|}{ Roller length, mm (in.) } & -------------------- & -------------------- & $13.9(35 / 64)$ \\
\hline \multicolumn{2}{|c|}{ Number of balls or rollers } & 14 & 19 & 16 \\
\hline \multicolumn{2}{|l|}{ Contact angle, deg } & 0 & 25 & 0 \\
\hline \multicolumn{2}{|l|}{ Load, $\boldsymbol{P}, \mathrm{N}(\mathrm{lb})$} & $1308(294)$ radial & $3843(864)$ thrust & 19657 (4 419) radial \\
\hline \multicolumn{2}{|c|}{ Dynamic load capacity, $\boldsymbol{C}_{\boldsymbol{D}}, \mathrm{N}(\mathrm{lb})$} & $16183(3638)$ & $29661(6668)$ & $79623(17900)$ \\
\hline \multirow{6}{*}{$\begin{array}{l}\text { Maximum Hertz stres } \\
\boldsymbol{S}_{\max }, \\
\mathrm{GPa}(\mathrm{ksi})\end{array}$} & \multicolumn{4}{|c|}{ Bearing steel balls or rollers } \\
\hline & Inner race & $1.72(250)$ & $1.72(250)$ & $1.72(250)$ \\
\hline & Outer race & $1.21(176)$ & $1.52(220)$ & $1.49(216)$ \\
\hline & \multicolumn{4}{|c|}{ Silicon Nitride balls or rollers } \\
\hline & Inner race & $1.94(282)$ & $1.94(282)$ & $1.89(274)$ \\
\hline & Outer race & $1.37(199)$ & $1.71(248)$ & $1.63(237)$ \\
\hline \multicolumn{2}{|l|}{ Operating speed, rpm } & 10000 & 10000 & 10000 \\
\hline
\end{tabular}

The Lundberg-Palmgren analysis (ref. 26) is based on the life of the inner and outer raceways of the bearing only. By benchmarking their analysis to a pre-1940 rolling-element bearing (unpublished) database and incorporating empirical material-geometry factors in their analysis, their equations incorporate the lives of the respective ball or roller sets in the calculated life of the bearing where the rolling elements are made from the same material as the races. However, where there is variance between the rolling-element material and the race material, the equations will yield an incorrect answer. As a result, if the hybrid bearing life factors of table 2 are applied against the entire bearing, they are also being inadvertently applied to steel rolling elements that are no longer component parts of the hybrid bearing. This results in a lower calculated bearing life for the hybrid bearings (see table 5 column, LundbergPalmgren life formula and rows, Basic Lundberg-Palmgren steel races, $\mathrm{Si}_{3} \mathrm{~N}_{4}$ balls, rollers).

To correct this discrepancy, it is necessary to apply Zaretsky's rule as contained in equations (11) to (13). The results are summarized in table 5 under the column captioned, "Zaretsky's rule." For the deepgroove ball bearing, the calculated life of the hybrid bearing with all steel races is increased by 20 percent over the life calculated from Lundberg-Palmgren. The calculated life of the angular-contact bearing is increased by 69 percent. For the cylindrical roller bearing, the calculated life of the hybrid bearing is increased by 29 percent. 


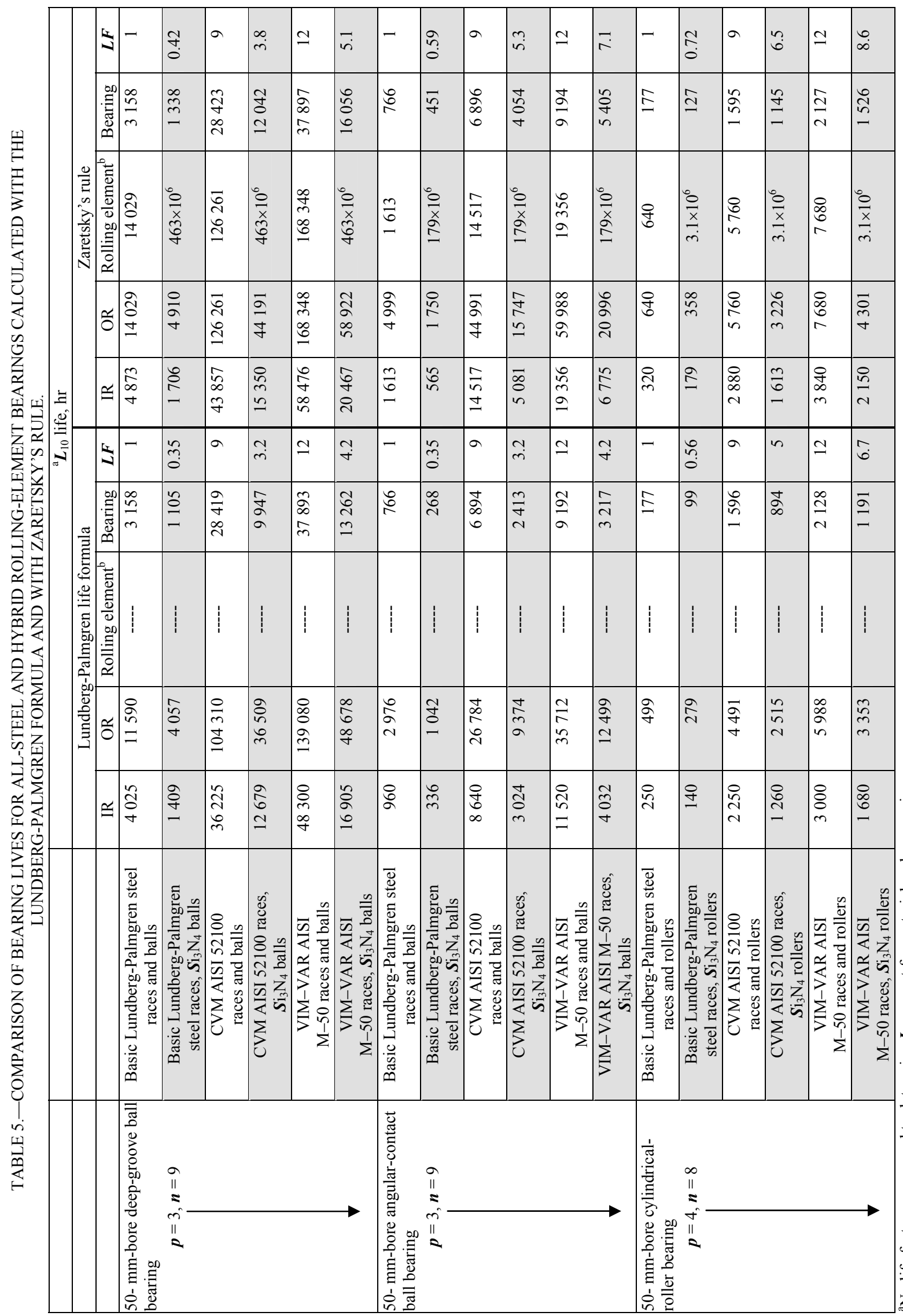


Anecdotal field experience suggests that even when applying Zaretsky's rule to the LundbergPalmgren equations, the life of the hybrid bearings are significantly higher than that calculated for hybrid bearings whose races are manufactured from AISI 52100 and AISI M-50 bearing steels. From table 5 under the column captioned, "Zaretsky's rule" the hybrid bearings are predicted to have a lower fatigue life than the all-steel bearings by 58 percent for deep-groove bearings, 41 percent for angular-contact bearings, and 28 percent for cylindrical roller bearings. Resultant life factors $\boldsymbol{L F}_{\boldsymbol{H}}$ based upon the Lundberg-Palmgren equations applying Zaretsky's rule are summarized in table 6.

TABLE 6.-SUMMARY OF LIFE FACTORS $\boldsymbol{L}_{\boldsymbol{H}}$ BASED ON LUNDBERGPALMGREN FORMULA AND ZARETSKY'S RULE FOR HYBRID SILICON NITRIDE ROLLING-ELEMENT BEARINGS

\begin{tabular}{|l|c|c|}
\hline \multicolumn{1}{|c|}{ Bearing type } & $\begin{array}{c}\text { Life factor, } \\
\boldsymbol{L F}_{\boldsymbol{H}}\end{array}$ & $\begin{array}{c}\text { Life reduction, } \\
\text { percent }\end{array}$ \\
\hline Deep-groove ball bearing & 0.42 & 58 \\
\hline Angular-contact ball bearing & 0.59 & 41 \\
\hline Cylindrical roller bearing & 0.72 & 28 \\
\hline
\end{tabular}

${ }^{a}$ Reduction from life of an all-steel bearing.

Can a hybrid bearing exhibit a statistically longer life than that calculated by the Lundberg-Palmgren equations for an all-steel bearing including life factors for material and processing? The answer must be a qualified yes. Based upon the Zaretsky life equation (equation (10)) and a large database that is now available (refs. 33 to 35), it can be reasonably concluded that the Lundberg-Palmgren formula underpredicts bearing life.

As previously discussed, the Lundberg-Palmgren formula for ball bearings incorporates a value of the load-life exponent $\boldsymbol{p}=3$ and for roller bearings, $\boldsymbol{p}={ }^{10} / 3$. These values are based on pre-1940, air-melt, AISI 52100 steel. Based on the data base reported by Parker and Zaretsky (ref. 36) and summarized in reference 37, for vacuum-processed post-1960 bearing steels, the value of the load-life exponent $\boldsymbol{p}$ for ball bearings is 4 and for roller bearings, 5 .

Using the Zaretsky equation, the lives of the VIM-VAR AISI M-50 all-steel and hybrid bearings were recalculated using the appropriate exponents discussed above. The results are summarized in table 7. For both all-steel and hybrid bearing lives, the results from the Zaretsky equation are presented as a ratio to the lives obtained from the basic Lundberg-Palmgren formula with and without life factors. A comparison of the life results from table 5 for all-steel and hybrid rolling-element bearings using the basic Lundberg-Palmgren equation with life factors, but without Zaretsky's rule, and the life results from table 7 using the Zaretsky equation are summarized in table 8. The calculated lives of the all-steel deepgroove and angular-contact ball bearings were increased by factors of 12.4 and 7.7, respectively, with respect to the Lundberg-Palmgren formulation. The calculated life of the roller bearing increased by a factor of 10.2. The resultant lives of the hybrid bearings increased by factors of 8.8, 5.5, and 7.7 for the deep-groove, angular-contact and cylindrical bearings, respectively.

What is most impressive about these calculations is that the resultant calculated lives of the hybrid bearings are 3.7, 3.2, and 5.5 times that calculated using the Lundberg-Palmgren equations for the allsteel VIM-VAR AISI M-50 deep-groove, angular-contact, and cylindrical bearings, respectively (table 8). This is illustrated in the data of references 21 and 22 for 6 -mm-bore hybrid deep-groove ball bearings run at $1200 \mathrm{rpm}$ and a maximum Hertz stress of $5.6 \mathrm{GPa}(810 \mathrm{ksi})$. The resultant $\boldsymbol{L}_{10}$ life of the bearing was $249 \mathrm{hr}$ or 5.3 times that calculated. Hence, the anecdotal observations of higher life for hybrid bearings than that calculated using the Lundberg-Palmgren equations appears merited. However, an all-steel bearing under the same load will always have a higher life than the equivalent hybrid bearing under nominal operating speeds and similar environments. Nevertheless, the life of high-speed hybrid bearings needs to be reassessed relative to the life of all-steel bearings. 
TABLE 7.-PREDICTED LIVES OF ALL-STEEL AND HYBRID 50-MM BORE BALL AND ROLLER BEARINGS CALCULATED WITH ZARETSKY LIFE EQUATION AND COMPARED WITH LIFE PREDICTION FROM LUNDBERG-PALMGREN EQUATION

\begin{tabular}{|c|c|c|c|c|c|c|c|}
\hline \multirow[t]{2}{*}{ Bearing type } & \multirow[t]{2}{*}{ Material } & \multicolumn{4}{|c|}{$\begin{array}{c}\boldsymbol{L}_{10} \text { life } \\
\mathrm{hr}\end{array}$} & \multicolumn{2}{|c|}{$\begin{array}{c}\text { Life ratio to } \\
\text { Lundberg-Palmgren } \\
\text { equation }\end{array}$} \\
\hline & & IR & OR & $\begin{array}{l}\text { Rolling } \\
\text { elements }^{\mathrm{a}}\end{array}$ & Bearing & $\begin{array}{l}\text { Without } \\
\text { life factors }\end{array}$ & $\begin{array}{l}\text { With life } \\
\text { factors }\end{array}$ \\
\hline \multirow{2}{*}{$\begin{array}{l}50 \text { - mm-bore } \\
\text { deep-groove } \\
\text { ball bearing } \\
\boldsymbol{p}=4, \boldsymbol{n}=12\end{array}$} & $\begin{array}{l}\text { All-steel VIM-VAR } \\
\text { AISI M-50 }\end{array}$ & $723.6 \times 10^{3}$ & $2.083 \times 10^{6}$ & $2.083 \times 10^{6}$ & $468.9 \times 10^{3}$ & 149 & 12.4 \\
\hline & $\begin{array}{l}\text { VIM-VAR AISI M- } \\
50 \text { races, } \\
\mathrm{Si}_{3} \mathrm{~N}_{4} \text { balls }\end{array}$ & $180.9 \times 10^{3}$ & $520.8 \times 10^{3}$ & $463 \times 10^{6}$ & $141.9 \times 10^{3}$ & 45 & 10.7 \\
\hline \multirow{2}{*}{$\begin{array}{l}50-\text { mm-bore } \\
\text { angular-contact } \\
\text { ball bearing } \\
\boldsymbol{p}=4, \boldsymbol{n}=12\end{array}$} & \begin{tabular}{|l|} 
All-steel VIM-VAR \\
AISI M-50
\end{tabular} & $149.4 \times 10^{3}$ & $463.1 \times 10^{3}$ & $149.4 \times 10^{3}$ & $71 \times 10^{3}$ & 93 & 7.7 \\
\hline & $\begin{array}{l}\text { VIM-VAR AISI M- } \\
50 \text { races, } \\
\mathrm{Si}_{3} \mathrm{~N}_{4} \text { balls } \\
\end{array}$ & $37.4 \times 10^{3}$ & $115.8 \times 10^{3}$ & $1.79 \times 10^{6}$ & $29.8 \times 10^{3}$ & 39 & 9.3 \\
\hline \multirow{2}{*}{$\begin{array}{l}50-\text { mm-bore } \\
\text { cylindrical- } \\
\text { roller bearing } \\
\boldsymbol{p}=5, \boldsymbol{n}=10\end{array}$} & $\begin{array}{l}\text { All-steel VIM-VAR } \\
\text { AISI M-50 }\end{array}$ & $39.4 \times 10^{3}$ & $78.8 \times 10^{3}$ & $78.8 \times 10^{3}$ & $21.8 \times 10^{3}$ & 123 & 10.2 \\
\hline & $\begin{array}{l}\text { VIM-VAR AISI M- } \\
50 \text { races, } \\
\mathrm{Si}_{3} \mathrm{~N}_{4} \text { rollers }\end{array}$ & $16.5 \times 10^{3}$ & $33.1 \times 10^{3}$ & $3.1 \times 10^{6}$ & $11.7 \times 10^{3}$ & 66 & 9.8 \\
\hline
\end{tabular}

${ }^{\mathrm{a}}$ Balls or rollers.

TABLE 8.--LIFE RATIO FOR ALL-STEEL AND HYBRID BEARINGS USING ZARETSKY EQUATION AND RESULTS FROM LUNDBERG-PALMGREN EQUATION

[Data from tables 5 and 7.]

\begin{tabular}{|c|c|c|c|c|}
\hline \multirow[t]{2}{*}{ Bearing type } & \multirow{2}{*}{$\begin{array}{c}\text { Life ratio of all-steel } \\
\text { VIM-VAR AISI } \\
\text { M-50 bearings: Zaretsky } \\
\text { equation to Lundberg- } \\
\text { Palmgren equation with } \\
\text { life factors }\end{array}$} & \multicolumn{3}{|c|}{$\begin{array}{c}\text { Life ratio of hybrid VIM-VAR AISI M-50 bearings with Zaretsky equation and } \\
\text { life factors to Lundberg-Palmgren equation for: }\end{array}$} \\
\hline & & $\begin{array}{c}\text { All-steel VIM-VAR AISI } \\
\text { M-50 bearings with life } \\
\text { factors }\end{array}$ & $\begin{array}{l}\text { Hybrid VIM-VAR AISI } \\
\text { M-50 bearings with life } \\
\text { factors }\end{array}$ & $\begin{array}{l}\text { Hybrid VIM-VAR AISI } \\
\text { M-50 bearings with life } \\
\text { factors using Zaretsky's } \\
\text { rule }\end{array}$ \\
\hline $\begin{array}{l}\text { 50-mm-bore } \\
\text { deep-groove } \\
\text { ball bearing } \\
\boldsymbol{p}=4, \boldsymbol{n}=12 \\
\end{array}$ & $\begin{array}{c}12.4 \\
\left(468.9 \times 10^{3} \div 37.9 \times 10^{3}\right)\end{array}$ & $\begin{array}{c}\mathbf{3 . 7} \\
\left(141.9 \times 10^{3} \div 37.9 \times 10^{3}\right)\end{array}$ & $\begin{array}{c}10.7 \\
\left(141.9 \times 10^{3} \div 13.3 \times 10^{3}\right)\end{array}$ & $\begin{array}{c}8.8 \\
\left(141.9 \times 10^{3} \div 16.1 \times 10^{3}\right)\end{array}$ \\
\hline $\begin{array}{l}50 \text {-mm-bore } \\
\text { angular-contact } \\
\text { ball bearing } \\
\boldsymbol{p}=4, \boldsymbol{n}=12\end{array}$ & $\begin{array}{c}7.7 \\
\left(71 \times 10^{3} \div 9.2 \times 10^{3}\right)\end{array}$ & $\begin{array}{c}\mathbf{3 . 2} \\
\left(29.8 \times 10^{3} \div 9.2 \times 10^{3}\right)\end{array}$ & $\begin{array}{c}9.3 \\
\left(29.8 \times 10^{3} \div 3.2 \times 10^{3}\right)\end{array}$ & $\begin{array}{c}5.5 \\
\left(29.8 \times 10^{3} \div 5.4 \times 10^{3}\right)\end{array}$ \\
\hline $\begin{array}{l}50-\text { mm-bore } \\
\text { cylindrical- } \\
\text { roller bearing } \\
p=5, n=10\end{array}$ & $\begin{array}{c}10.3 \\
\left(21.8 \times 10^{3} \div 2.1 \times 10^{3}\right)\end{array}$ & $\begin{array}{c}\mathbf{5 . 5} \\
\left(11.7 \times 10^{3} \div 2.1 \times 10^{3}\right)\end{array}$ & $\begin{array}{c}9.8 \\
\left(11.7 \times 10^{3} \div 1.2 \times 10^{3}\right)\end{array}$ & $\begin{array}{c}7.7 \\
\left(11.7 \times 10^{3} \div 1.5 \times 10^{3}\right)\end{array}$ \\
\hline
\end{tabular}

The silicon nitride rolling elements were the life-limiting component in early hybrid bearings. This is illustrated in the hybrid-ball-bearing life tests of Morrison et al. (ref. 20) that resulted in fatigue spalling of the silicon nitride balls. Yet, through process development over a period of three decades, the inherent flaws contained in the silicon nitride material have been mitigated to produce consistently reliable material (refs. 2 and 3). Thus, should hybrid bearings fail as a result of spalling of the silicon nitride rolling elements prior to their calculated service life, the quality of the specific lot of silicon nitride material should be brought into question. 


\section{Summary of Results}

Three decades have passed since the introduction of silicon nitride rollers and balls into conventional rolling-element bearings. For a given applied load, the contact (Hertz) stress in a hybrid bearing will be higher than an all-steel rolling-element bearing, where all the components are manufactured from hardened bearing steel. Using the Lundberg-Palmgren equations, the life of the hybrid bearing is predicted to be less than an all-steel bearing of the same type. However, experimental data and anecdotal observations suggest higher lives for hybrid bearings than those calculated using the Lundberg-Palmgren equations, even when the differences in material properties between the rolling elements and races including the Hertz stress-life exponents were taken into consideration. The rolling-element life as well as the race lives were used to determine the resultant bearing life of the hybrid and all-steel bearings. Based upon the Zaretsky life equation, the predicted lives of hybrid silicon nitride bearings were theoretically compared with that predicted for all-steel bearings and the actual lives reported in the literature. The following results were obtained:

1. An all-steel bearing under the same load will have a longer life than the equivalent hybrid bearing under nominal operating speeds and similar environments.

2. Life factors derived for hybrid bearings based upon the Lundberg-Palmgren equations are dependent on the bearing type. The life factors for deep-groove, angular-contact, and cylindrical roller hybrid bearings are $0.42,0.59$, and 0.72 , respectively. These life factors are multiplied by the calculated life of an all-steel bearing using the Lundberg-Palmgren formula to obtain the hybrid bearing life.

3. The Lundberg-Palmgren equations underpredict bearing life. Under nominal operating speeds, the resultant calculated lives of the deep-groove, angular-contact, and cylindrical roller hybrid bearings with races made of post-1960 bearing steel increased by factors of 3.7, 3.2, and 5.5, respectively, from those calculated using the Lundberg-Palmgren equations.

\section{References}

1. Dee, C.W. (1970), "Silicon Nitride-Tribological Applications of a Ceramic Material," Tribology, 3, 2, pp. 89-92.

2. Chao, L.Y., Shetty, D.K., Adair, J.H., and Mecholsky, J.J., Jr., (1995), "Development of Silicon Nitride for Rolling-Contact Applications: A Review," Jour. Materials Education 17, 5-6, pp. 245 303.

3. Wang, L., Snidle, R.W., and Gu, L., (2000), "Rolling Contact Silicon Nitride Bearing Technology: A Review of Recent Research," Wear, 246, pp. 159-173.

4. Scott, D., Blackwell, J., and McCullah, P.J., (1971), "Silicon Nitride as a Rolling Bearing MaterialA Preliminary Assessment," Wear, 17, 1, pp. 73-82.

5. Scott, D., and Blackwell, J., (1973), "Hot-Pressed Silicon Nitride as a Rolling Bearing Material—A Preliminary Assessment," Wear, 24, 1, pp. 61-67.

6. Baumgartner, H.R., and Whieldon, W.M., (1973), "Rolling Contact Fatigue Performance of HotPressed Silicon Nitride versus Surface Preparation Techniques," in: Surfaces and Interfaces of Glass and Ceramics, V.D. Frechette, W.C. LaCourse, and V.L. Burdick, eds., Plenum Press, New York, pp. 179-193.

7. Baumgartner, H.R., (1973), "Evaluation of Roller Bearing Contacting Hot Pressed Silicon Nitride Rolling Elements," in: Ceramics for High Performance Applications, J.J. Burke, E. Gorum, and R.N. Katz, eds., Brook Hill Publishing Co., Chestnut Hill, MA, pp. 713-727.

8. Baumgartner, H.R., Lundberg, D.V., and Whieldon, W.M., (1973), "Silicon Nitride in Rolling contact Bearings," Norton Co., Worcester, MA (available NTIS, AD-A031560). 
9. Parker, R.J., and Zaretsky, E.V., (1974), Rolling-Element Fatigue Life of Silicon Nitride Balls,” NASA TN D-7794.

10. Zaretsky, E.V., (1989), "Ceramic Bearings for Use in Gas Turbine Engines," ASME Jour. Gas Turbines and Power, 111, 1, pp. 146-157.

11. Sundberg, D.V., (1974), Ceramic Roller Bearings for High Speed and High Temperature Applications, SAE Paper No. 740241.

12. Baumgartner, H.R. and Cowley, P.E., (1975), "Silicon Nitride in Rolling Contact Bearings," AMMRC-CTR-76-5 (available NTIS AD-A025350).

13. Baumgartner, H.R., Calvert, G.S., and Cowley, P.E., (1976), "Ceramic Materials in Rolling Contact Bearings,” Norton Co., Worcester, MA (available NTIS AD-A031560).

14. Reddecliff, J.M., and Valorie, R., (1976), "The Performance of a High-Speed Ball Thrust Bearing Using Silicon Nitride Balls,” ASME Jour. of Lubrication Tech., 98, 4, pp. 553-563.

15. Miner, J.R., Grace, W.A., and Valorie, R., (1981), "A Demonstration of High-Speed Gas Turbine Bearings Using Silicon Nitride Rolling Elements," Lubrication Engineering, 37, 8, pp. 462-464, 473-478.

16. Miner, J.R., Dell, J., Galbato, A.T., and Ragen, M.A., (1998), "F117-PW-100 Hybrid Ball Bearing Ceramic Technology Insertion," ASME Jour. of Engineering for Gas Turbines and Power, 118, 2, pp. 434-442.

17. Bailey, T.E., (1984), "Ceramic Roller Bearing Development Program,” NAPC-PE-106-C (available NTIS, AD-B086767L).

18. Hosang, G.W., (1987), "Results and Design Techniques From the Application of Ceramic Ball Bearings to the MERADCOM 10KW Turbine," AIAA Paper No. 87-1844.

19. Parker, R.J., and Zaretsky, E.V., (1975), "Fatigue Life of High-Speed Ball Bearings With Silicon Nitride Balls," ASME Jour. of Lubrication Tech., 97, 3, pp. 553-563.

20. Morrison, F.R., McCool, J.I., Yonushonis, T.M., and Weinberg, P., (1984), "The Load-Life Relationship for M-50 Steel Bearings With Silicon Nitride Balls," Lubrication Engineering, 40, 3, pp.153-159.

21. Komeya, K., and Kotani, H., (1986), "Development of Ceramic Antifriction Bearing," JSAE Review, 3,3, pp. $72-79$.

22. Tanimoto, K., and Ikeda, T., (2000), "Evaluation of Extra-Small Ceramic Ball Bearings," KOYO Engineering Journal English Edition, 156E (2000), pp. 23-29.

23. Tanimoto, K., Kajihara, K. and Yanai, K., (2000), "Hybrid Ceramic Ball Bearings for Turbochargers," SAE Paper No. 2000-01-1339.

24. Zaretsky, E.V. (1992), STLE Life Factors for Rolling Bearings, STLE SP-34, STLE, Park Ridge, IL, pp. 92-95.

25. Zaretsky, E.V. (1997), "Rolling Bearing and Gear Materials," Tribology for Aerospace Applications, E.V. Zaretsky, ed., STLE SP-37, STLE, Park Ridge, IL, pp. 432-442.

26. Lundberg, G., and Palmgren, A. (1947), "Dynamic Capacity of Rolling Bearings," Acta Polytechnica, 1,3 , Stockholm.

27. Weibull, W. (1939), "A Statistical Theory of the Strength of Materials," Ingeniors Etanskaps Akademien-Handlinger, 151.

28. Weibull, W. (1939), "The Phenomenon of Rupture of Solids," Ingeniors Vetenskaps Akademien, 153.

29. Weibull, W. (1951), "A Statistical Distribution Function of Wide Applicability," ASME Jour. of Applied Mechanics, 18, 3, pp. 293-297.

30. Lundberg, G., and Palmgren, A. (1952), "Dynamic Capacity of Roller Bearings," Ingeniors Etanskaps Akademien-Handlinger, 210.

31. Zaretsky, E.V. (1994), "Design for Life, Plan for Death, Machine Design, 66, 15, Aug., 1994, pp. 55-59.

32. Jones, A.B., (1946), Analysis of Stresses and Deflections, Vols. I and II, General Motors, New Departure Division, Bristol, CT. 
33. Harris, T.A. (1995), "Final Report-Establishment of a New Rolling Bearing Contact Life Calculation Method," U.S. Naval Air Warfare Center, Aircraft Division Trenton, Contract No. N68335-93-C0111.

34. Harris, T.A., and McCool, J.I. (1996), "On Accuracy of Rolling Bearing Fatigue Life Prediction," ASME Jour. of Trib., 118, 2, pp. 297-310.

35. Vlcek, B.L., Hendricks, R.C., and Zaretsky, E.V. (2003), "Determination of Rolling-Element Fatigue Life from Computer Generated Bearing Tests," Trib. Trans., 46, 4, pp. 479-493.

36. Parker, R.J., and Zaretsky, E.V., (1972), "Reevaluation of the Stress-Life Relation in Rolling-Element Bearings," NASA TN D-6745.

37. Zaretsky, E.V. (1997), "Rolling Bearing and Gear Materials," Tribology for Aerospace Applications, E.V. Zaretsky, ed., STLE SP-37, STLE, Park Ridge, IL, pp. 398-405. 


\section{Appendix A \\ Effect of Modulus of Elasticity and Poisson's Ratio on Contact Stress and Life}

\section{Point Contact Stress and Life}

The following analysis is from Zaretsky (ref. 10). From Hertz theory for two spheres of radii $\boldsymbol{R}_{\boldsymbol{a}}$ and $\boldsymbol{R}_{\boldsymbol{b}}$ in contact (ref. 32), the maximum compressive stress $\boldsymbol{S}_{\boldsymbol{m a x}}$ is

$$
S_{\max }=\frac{3 \boldsymbol{P}_{\boldsymbol{o}}}{2 \pi \boldsymbol{r}^{2}}
$$

where $\boldsymbol{P}_{\boldsymbol{o}}=$ normal load and $\boldsymbol{r}=$ contact radius. For two spheres in contact, the Hertzian contact area is a circle with radius

$$
\boldsymbol{r}=\left[\frac{3 \boldsymbol{P}_{o}\left(v_{a}+v_{b}\right)}{8\left(\frac{2}{\boldsymbol{R}_{a}}+\frac{2}{\boldsymbol{R}_{b}}\right)}\right]^{1 / 3}
$$

For two spheres of equal radius

$$
\boldsymbol{R}_{a}=\boldsymbol{R}_{b}=\boldsymbol{R}
$$

then

$$
\boldsymbol{r}=\left[\frac{3 \boldsymbol{P}_{\boldsymbol{o}} \boldsymbol{R}\left(\mathrm{v}_{a}+\mathrm{v}_{\boldsymbol{b}}\right)}{32}\right]^{1 / 3}
$$

where

$$
v_{a}=\frac{4\left(1-\delta_{a}^{2}\right)}{Y_{a}}
$$

and

$$
v_{b}=\frac{4\left(1-\delta_{b}^{2}\right)}{Y_{b}}
$$

and $\boldsymbol{Y}=$ modulus of elasticity; $\boldsymbol{\delta}=$ Poisson ratio. Then 


$$
\begin{aligned}
\boldsymbol{r} & =\boldsymbol{K}_{1}\left[\frac{1-\delta_{a}^{2}}{\boldsymbol{Y}_{\boldsymbol{a}}}+\frac{1-\delta_{b}^{2}}{\boldsymbol{Y}_{\boldsymbol{b}}}\right]^{1 / 3} \\
& =\boldsymbol{K}_{1}\left[\frac{\boldsymbol{Y}_{\boldsymbol{b}}\left(1-\delta_{a}^{2}\right)+\boldsymbol{Y}_{\boldsymbol{a}}\left(1-\delta_{b}^{2}\right)}{\boldsymbol{Y}_{\boldsymbol{a}} \boldsymbol{Y}_{\boldsymbol{b}}}\right]^{1 / 3}
\end{aligned}
$$

where

$$
\boldsymbol{K}_{1}=\left[\frac{3 \boldsymbol{P}_{\boldsymbol{o}} \boldsymbol{R}}{8}\right]^{1 / 3}
$$

Substituting equations (A5a) and (A5b) into equation (A1)

$$
\boldsymbol{S}_{\text {max } \mathrm{H}}=\boldsymbol{K}_{2}\left[\frac{\boldsymbol{Y}_{a} \boldsymbol{Y}_{b}}{\boldsymbol{Y}_{\boldsymbol{b}}\left(1-\delta_{a}^{2}\right)+\boldsymbol{Y}_{a}\left(1-\delta_{b}^{2}\right)}\right]^{2 / 3}
$$

where

$$
\boldsymbol{K}_{2}=\frac{6}{\pi}\left[\frac{\boldsymbol{P}_{\boldsymbol{o}}}{9 \boldsymbol{R}^{2}}\right]^{1 / 3}
$$

For steel on steel

$$
\boldsymbol{S}_{\max _{s}}=\boldsymbol{K}_{2}\left[\frac{\boldsymbol{Y}_{\boldsymbol{s}}}{2\left(1-\delta_{s}^{2}\right)}\right]^{2 / 3}
$$

\section{Line Contact Stress and Life}

From Hertz theory for two rollers of radii $\boldsymbol{R}_{\boldsymbol{a}}$ and $\boldsymbol{R}_{\boldsymbol{b}}$ in contact, and each of length $\boldsymbol{l}_{\boldsymbol{t}}$, the resultant pressure (contact) area is a rectangle of width $2 \boldsymbol{b}$ and length $\boldsymbol{l}_{\boldsymbol{r}}$ (ref. 32). The maximum compressive (Hertz) stress is

$$
S_{\max }=\frac{2 P_{0}}{\pi b l_{t}}
$$

where from reference 32 


$$
\boldsymbol{b}=\left[\frac{\boldsymbol{P}_{o}\left(v_{a}+v_{b}\right)}{\pi \boldsymbol{l}_{t}\left(\frac{1}{\boldsymbol{R}_{a}}+\frac{1}{\boldsymbol{R}_{b}}\right)}\right]^{1 / 2}
$$

From equations (A4b), (A4c), and (A9),

$$
\boldsymbol{b}=\boldsymbol{K}_{3}\left[\frac{\boldsymbol{Y}_{\boldsymbol{b}}\left(1-\delta_{a}^{2}\right)+\boldsymbol{Y}_{\boldsymbol{a}}\left(1-\delta_{b}^{2}\right)}{\boldsymbol{Y}_{\boldsymbol{a}} \boldsymbol{Y}_{\boldsymbol{b}}}\right]^{1 / 2}
$$

where

$$
\boldsymbol{K}_{3}=\left[\frac{4 \boldsymbol{P}_{o}}{\pi \boldsymbol{l}_{\boldsymbol{t}}\left(\frac{1}{\boldsymbol{R}_{a}}+\frac{1}{\boldsymbol{R}_{b}}\right)}\right]^{1 / 2}
$$

For 2 rollers of equal radius

$$
\begin{gathered}
\boldsymbol{R}_{a}=\boldsymbol{R}_{b}=\boldsymbol{R} \\
\boldsymbol{S}_{\text {max }_{H}}=\boldsymbol{K}_{4}\left[\frac{\boldsymbol{Y}_{a} \boldsymbol{Y}_{b}}{\boldsymbol{Y}_{b}\left(1-\delta_{a}^{2}\right)+\boldsymbol{Y}_{a}\left(1-\delta_{b}^{2}\right)}\right]^{1 / 2}
\end{gathered}
$$

where

$$
\boldsymbol{K}_{4}=\left[\frac{2 \boldsymbol{P}_{\boldsymbol{o}}}{\pi \boldsymbol{l}_{\boldsymbol{t}} \boldsymbol{R}}\right]^{1 / 2}
$$

For steel on steel

$$
\boldsymbol{S}_{\text {max }_{s}}=\boldsymbol{K}_{4}\left[\frac{\boldsymbol{Y}_{\boldsymbol{s}}}{2\left(1-\delta_{s}^{2}\right)}\right]^{1 / 2}
$$




\section{Life Factor}

Bearing life is related to maximum Hertz stress where

$$
\frac{\boldsymbol{L} \sim 1}{\boldsymbol{S}_{\max }^{n}}
$$

Hybrid bearing life can be expressed in terms of the all-steel bearing life where

$$
L_{H}=L_{s}\left(\frac{S_{\max _{s}}}{S_{\max _{H}}}\right)^{n}
$$

The life factor is

$$
L F_{H}=L_{H} / L_{s}=\left(\frac{S_{\text {max }_{s}}}{S_{\max _{H}}}\right)^{n}
$$

In general, from equations (A6a) and (A12a) for hybrid bearings, the maximum Hertz stress is

$$
S_{\max _{H}} \sim\left[\frac{Y_{s} Y_{c}}{Y_{c}\left(1-\delta_{s}^{2}\right)+Y_{c}\left(1-\delta_{c}^{2}\right)}\right]^{z}
$$

and

$$
\boldsymbol{S}_{\text {max }_{s}} \sim\left[\frac{\boldsymbol{Y}_{s}}{2\left(1-\delta_{s}^{2}\right)}\right]^{z}
$$

Combining equations (A17) and (A18) into equation (A15),

$$
\boldsymbol{L F}_{\boldsymbol{H}}=\left[\frac{1}{2}+\frac{\boldsymbol{Y}_{\boldsymbol{s}}\left(1-\delta_{c}^{2}\right)}{2 \boldsymbol{Y}_{c}\left(1-\delta_{s}^{2}\right)}\right]^{z \boldsymbol{n}}
$$

where for point contact, $\boldsymbol{z}={ }^{2} / 3$ and line contact, $\boldsymbol{z}=1 / 2$. 


\section{Appendix B \\ Determining the Hertz Stress-Life Relation for Silicon Nitride}

The experimental results reported in the literature for silicon nitride in point contact reports a Hertz stress-life exponent $\boldsymbol{n}$ of 16 . However, there is no Hertz stress-life exponent reported for silicon nitride in line contact. From the Lundberg-Palmgren equation (eqs. (2) and (15a) of the text),

$$
\begin{aligned}
\boldsymbol{L} & \sim\left(\frac{1}{\tau_{o}}\right)^{c / e}\left(\frac{1}{V}\right)^{1 / e}\left(Z_{0}\right)^{h / e} \\
& \sim \frac{1}{S_{\max }^{n}}
\end{aligned}
$$

From Hertz theory (ref. 29) for point contact

$$
\begin{aligned}
\tau_{o} & \sim S_{\max } \\
V & \sim S_{\max }^{2} \\
Z_{o} & \sim S_{\max }
\end{aligned}
$$

From (B1) and (B2),

$$
\begin{gathered}
L \sim\left(\frac{1}{S_{\max }}\right)^{c / e}\left(\frac{1}{S_{\max }^{2}}\right)^{1 / e}\left(S_{\max }\right)^{\boldsymbol{h} / \boldsymbol{e}} \sim\left(\frac{1}{S_{\max }^{n}}\right) \\
n=\frac{\boldsymbol{c}+2-\boldsymbol{h}}{e}
\end{gathered}
$$

For silicon nitride in point contact, from Zaretsky (ref. 10), $\boldsymbol{n}=16$ and $\boldsymbol{e}=1.7$. From LundbergPalmgren, $\boldsymbol{h}=2.31$. Solving for $\boldsymbol{c}$

$$
\begin{aligned}
\boldsymbol{c} & =(16)(1.7)-2+2.3 \\
& =27.2-2+2.3 \\
& =27.5
\end{aligned}
$$

From Hertz theory for line contact,

$$
\begin{aligned}
\tau_{o} & \sim S_{\max } \\
V & \sim S_{\max } \\
Z_{o} & \sim S_{\max }
\end{aligned}
$$


From equation (B1),

$$
\begin{aligned}
\boldsymbol{L} \sim\left(\frac{1}{\boldsymbol{S}_{\max }}\right)^{27.5 / 1.7}\left(\frac{1}{\boldsymbol{S}_{\max }}\right)^{1 / 1.7}\left(\boldsymbol{S}_{\max }\right)^{2.3 / 1.7} \\
\sim \frac{1}{\boldsymbol{S}_{\max }^{\boldsymbol{n}}} \\
\boldsymbol{n}=\frac{27.5+1-2.3}{1.7} \\
=15.4
\end{aligned}
$$

where for convenience of illustration, $\boldsymbol{n}=15.5$ will be used for line contact, and 16 for point contact. 


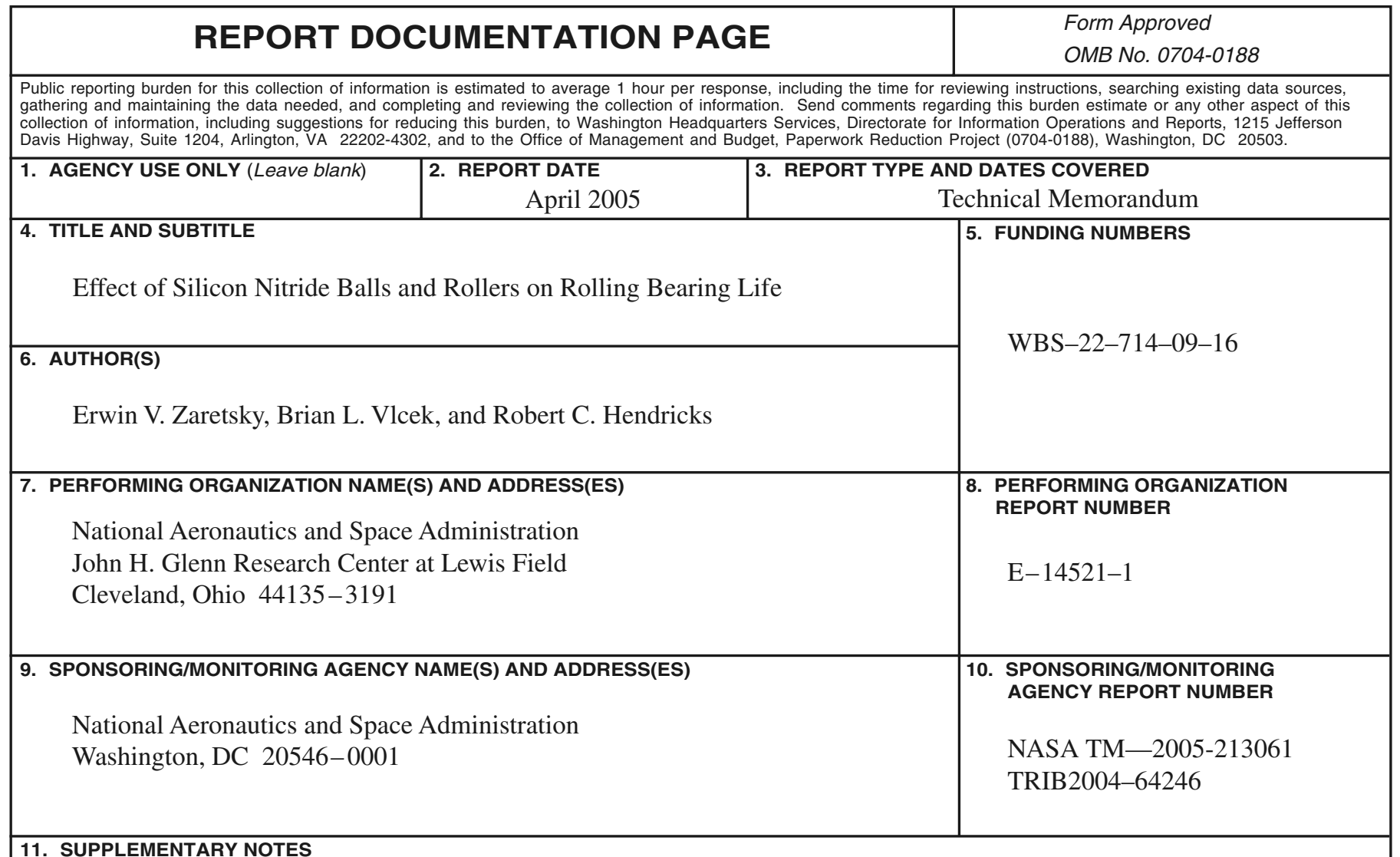

\section{SUPPLEMENTARY NOTES}

Prepared for the 2004 International Joint Tribology Conference cosponsored by the American Society of Mechanical Engineers and the Society of Tribologists and Lubrication Engineers, Long Beach, California, October 24-27, 2004. Erwin V. Zaretsky and Robert C. Hendricks, NASA Glenn Research Center; and Brian L. Vlcek, Georgia Southern University, Statesboro, Georgia 30460. Responsible person, Erwin V. Zaretsky, organization code RS, 216-433-3241.

\begin{tabular}{|l|l|}
\hline 12a. DISTRIBUTION/AVAILABILITY STATEMENT & 12b. DISTRIBUTION CODE
\end{tabular}

Unclassified - Unlimited

Subject Categories: 37, 38, and 39

Available electronically at http://gltrs.grc.nasa.gov

This publication is available from the NASA Center for AeroSpace Information, 301-621-0390.

13. ABSTRACT (Maximum 200 words)

Three decades have passed since the introduction of silicon nitride rollers and balls into conventional rolling-element bearings. For a given applied load, the contact (Hertz) stress in a hybrid bearing will be higher than an all-steel rollingelement bearing. The silicon nitride rolling-element life as well as the lives of the steel races were used to determine the resultant bearing life of both hybrid and all-steel bearings. Life factors were determined and reported for hybrid bearings. Under nominal operating speeds, the resultant calculated lives of the deep-groove, angular-contact, and cylindrical roller hybrid bearings with races made of post-1960 bearing steel increased by factors of 3.7, 3.2, and 5.5, respectively, from those calculated using the Lundberg-Palmgren equations. An all-steel bearing under the same load will have a longer life than the equivalent hybrid bearing under the same conditions. Under these conditions, hybrid bearings are predicted to have a lower fatigue life than all-steel bearings by 58 percent for deep-groove bearings, 41 percent for angular-contact bearings, and 28 percent for cylindrical roller bearings.

14. SUBJECT TERMS

15. NUMBER OF PAGES

Hybrid rolling bearings; Bearing life prediction; Silicon nitride rolling elements 30

\begin{tabular}{|c|c|c|}
\hline $\begin{array}{c}\text { 17. SECURITY CLASSIFICATION } \\
\text { OF REPORT } \\
\text { Unclassified }\end{array}$ & $\begin{array}{c}\text { 18. SECURITY CLASSIFICATION } \\
\text { OF THIS PAGE } \\
\text { Unclassified }\end{array}$ & $\begin{array}{c}\text { 19. SECURITY CLASSIFICATION } \\
\text { OF ABSTRACT } \\
\text { Unclassified }\end{array}$ \\
\hline
\end{tabular}

NSN 7540-01-280-5500

Standard Form 298 (Rev. 2-89) 

